\title{
The Metabolism of 5-methylcytosine Residues in DNA
}

\author{
R. MURÍN ${ }^{1}$, M. ABDALLA ${ }^{1}$, N. MURÍNOVÁ ${ }^{2}$, J. HATOK ${ }^{1}$, D. DOBROTA ${ }^{1}$ \\ ${ }^{1}$ Department of Medical Biochemistry, Jessenius Faculty of Medicine in Martin, Comenius \\ University in Bratislava, Slovak Republic, ${ }^{2}$ Faculty of Pharmacy in Hradec Králové, Charles \\ University, Hradec Králové, Czech Republic
}

Received November 8, 2016

Accepted December 1, 2017

On-line March 12, 2018

\section{Summary}

The fundamental biochemical processes of 5-methylcytosine (5-mC) synthesis, maintenance, conversion and removal determine the time and spatial pattern of DNA methylation. This has a strong effect on a plethora of physiological aspects of cellular metabolism. While the presence of $5-\mathrm{mC}$ within the promoter region can silence gene expression, its derivative 5-hydroxymethylcytosine exerts an opposite effect. Dysregulations in the metabolism of 5-mC lead to an altered DNA methylation pattern which is linked with a disrupted epigenome, and are considered to play a significant part in the etiology of several human diseases. A summary of recent knowledge about the molecular processes participating in DNA methylation pattern shaping is provided here.

\section{Key words}

Epigenetics - DNA methylation - DNA demethylation • 5-methylcytosine

\section{Corresponding authors}

R. Murín and D. Dobrota, Department of Medical Biochemistry, Jessenius Faculty of Medicine in Martin, Comenius University in Bratislava, Malá Hora 4D, 03601 Martin, Slovak Republic. E-mail: murin@jfmed.uniba.sk

\section{Introduction}

Emerging evidence indicates that in the etiology of numerous human diseases, their pathological phenotype is a consequence of disturbances in epigenetic regulatory mechanisms with an impact on gene expression (Aslani et al. 2016, Kwak and Park 2016, Ludwig et al. 2016). Contrary to genetic mutations, which affect the DNA sequence, disorders in epigenetic regulation may alter gene expression via silencing or overexpression (Weinberg and Morris 2016, Willis et al. 2016). Aberrant expression of genes may underlie the changes leading to switching of the phenotype from normal to pathological (Gupta et al. 2009). Recently, the expanding group of "epigenetic disorders" has come to include diverse diseases such as neurological (Carrick et al. 2016), psychological (Klengel and Binder 2015), immunological (Ciechomska and O'Reilly 2016), cardiovascular (Ahuja et al. 2017, Kim and Stansfield 2017), neoplastic (Feinberg et al. 2016, Upchurch et al. 2016) and metabolic diseases (Kamat et al. 2016, Hur et al. 2017). Increasing knowledge about the etiology of epigenetic disorders is aligned with the progress of therapies focusing on prevention or reversal of the pathological phenotype through modulation of the activity of several molecular members of the epigenetic regulatory machinery (Bär et al. 2016, Kgatle et al. 2016, Mund and Lyko 2010, Yoo and Jones 2006).

\section{DNA methylation}

The term epigenetics defines the heritable changes in gene function that do not involve changes in their DNA sequence and the processes through which genes produce their effect on the phenotype of the organism (Ho and Burggren 2010). Epigenetic regulation plays an essential physiological role in the activation or 
silencing of appropriate genes during development, differentiation, and environmentally stimulated phenotypic plasticity. Within the cells, DNA and histones are chemically modified by covalent modification of several distinct groups that lead to the changes in chromatid structure and chromosomal architecture. The covalent modifications of DNA and histones are reversible and dynamic depending on the developmental state, the tissue specificity and the influence of environmental factors. At the molecular level, covalent modifications of DNA participate in the regulation of chromosomal level of condensation, which can exist in a transcriptionally active or inactive states named as euchromatin or heterochromatin, respectively. In addition to changes in chromosomal structures that exert an effect on transcriptional activity the level of already synthesized gene-specific mRNA molecules may be downregulated in the presence of specific miRNA molecules (Rassoulzadegan et al. 2006, Saetrom et al. 2007).

In human cells, the predominant covalent modification of DNA is the enzymatically catalyzed methylation of cytosine residues to 5-methylcytosine (5-mC; D'Alessio and Szyf 2006, Gupta et al. 2010, Zilberman and Henikoff 2007). The methylation of DNA in differentiated cells occurs primarily but not solely at CG residues present in CG islands. The CG islands comprise approximately $60 \%$ of the nucleotides at the 5 '-end region of the gene promoters, wherein approximately $60-80 \%$ of the CG residues remain methylated after differentiation. The methylation of CG residues at promoter regions represses transcription, whereas the active promoters remain un-methylated. DNA methylation either directly prevents binding of transcription factors to their target binding sites (Prendergast and Ziff 1991) or provides binding sites for methyl-binding domain containing proteins that are able to suppress gene repression (Nan et al. 1998) or control alternative promotor usage (Rauch et al. 2009). In addition, DNA methylation prevents chromosomal instability by silencing non-coding DNA and transposable DNA elements. Contrary to methylation in promoter and enhancer regions, the presence of 5-methylcytosine residues within the gene sequences is positively correlated with its transcription (Lister et al. 2009, Rauch et al. 2009).

The methylation of cytosine is enzymatically catalyzed by a group of enzymes of the DNA methyltransferase family [E. C. number 2.1.1.37, recommended name: DNA (cytosine-5-)-methyltransferase] consisting of three isoenzymes. DNA methyltransferase (Dnmt) 1 initiates de novo methylation (Bestor 1992), whereas Dnmt3a and Dnmt3b are involved in maintaining the methylation pattern (Okano et al. 1999). The donor of methyl groups is S-adenosylmethionine (SAM) and its availability is dependent on the capacity of the SAM cycle to generate SAM and regenerate methionine from homocysteine. The sufficient resynthesis of methionine from homocysteine may be limited by availability of vitamins $B_{12}$ and folic acid as well as enzymatic activity of methionine synthase. A deficiency of cells to resynthesize S-adenosylmethionine, due to insufficient levels of both vitamins may negatively affect the DNA methylation status (Niculescu and Zeisel 2002, James et al. 2003, Ulrey et al. 2005, Chang et al. 2011, FernàndezRoig et al. 2012). In addition, the increased level of unprocessed homocysteine may disturb the methylation reactions (Škovierová et al. 2015) by inhibiting the enzymatic activity of methyltransferases including Dnmts (Lin et al. 2014).

In mammalian cells, de novo methylation of cytosine by Dnmt3a is stimulated by non-catalytic paralogue Dnmt31 (Liao et al. 2012). In addition, similarly to Dnmt3a and Dnmt3b, Dnmt31 may interact with histone deacetylase (Aapola et al. 2002, Deplus et al. 2002) and block the transcription process. The space specific methylation by Dnmt1 is also regulated through its interaction with the protein UHRF1, which is able to sense the presence of methylated histone 3 and subsequently can recruit Dnmt1 to its proximity (Bronner et al. 2013). Both proteins, Dnmt31 and UHRF1, possess the capability to assign DNA methylation patterns with histone epigenetic marks, covalent modifications that may influence nucleosome positioning (Harikrishnan et al. 2005, Wysocka et al. 2006) and chromatin remodeling (Portela and Esteller 2010).

\section{Removal of the methyl moiety}

The methylation pattern of DNA is dynamic and varies in cell specific and time dependent manners. In contrast to methylation, the reverse process of $5-\mathrm{mC}$ conversion to cytosine is not straightforward and requires several consecutive steps. Based on the enzymatic mechanisms underlying the demethylation, passive and active pathways can be recognized (Chen et al. 2013, Franchini et al. 2012, Piccolo and Fisher 2014, Wu and Zhang 2014).

Methyl moieties can be lost from the genome by 
blocking Dnmt activity during cell replication, which is considered to be a passive DNA-demethylation pathway. Suppressed expression, enhanced degradation, nuclear exclusion or enzymatic inhibition of DNA methyltransferase activity will definitely lead to a progressive decline in the presence of 5-mC within the genome upon DNA replication. In mammals, the process of passive demethylation is supposed to occur following fertilization and during gametogenesis (Chen and Riggs 2011, Franchini et al. 2012, Piccolo and Fisher 2014).
The active DNA-demethylation pathway involves several specific enzymes that are capable of converting 5-mC residues to products, which can subsequently be enzymatically substituted by cytosine (Fig. 1). The proteins from the ten-eleven translocation (TET) family are involved in the enzymatic conversion of 5-mC into its oxidized derivatives (Weber et al. 2016). TET proteins are capable of converting $5-\mathrm{mC}$ in a series of reactions to 5-hydroxymethylcytosine, 5-formylcytosine and 5-carboxylcytosine (Piccolo and Fisher 2014).

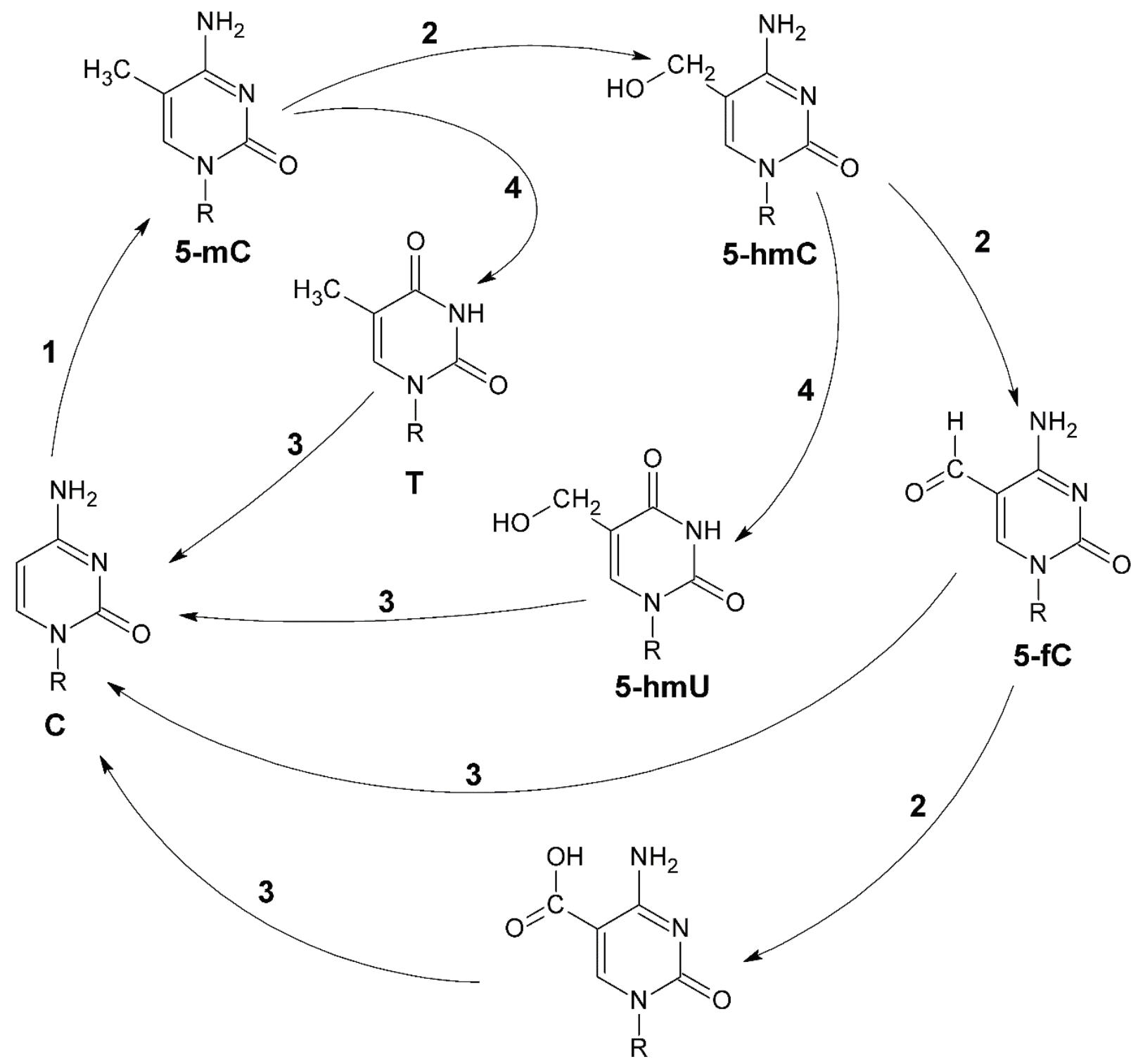

5-caC

Fig. 1. Simplified scheme of active DNA-demethylation processes. A genomic cytosine nucleobase can be methylated by DNA methyltransferase (1) to generate a 5-methylcytosine residue (5-mC), which can be further enzymatically metabolized in two distinct pathways. TET enzymes can catalyze the oxidation of the methyl moiety of $5-\mathrm{mC}$ in an ordered sequence of reactions (2) to 5-hydroxymethylcytosine (5-hmC), 5-formylcytosine (5-fC) and 5-carboxylcytosine (5-caC). Both, 5-fC and 5-caC, might be substituted by cytosine in a thymine glycosylase catalyzed base excision repair (BER) process (3). Deamination (4) of 5-mC and 5-hmC by the activation-induced cytidine deaminase/apolipoprotein B mRNA editing enzyme generates thymidine (T) and 5-hydroxymethyluracyl (5-hmU) residues, respectively. They are both exchanged to cytosine by the BER process (3). 
Oxidized derivatives of cytosine - 5-formylcytosine and 5-carboxylcytosine - can be removed from DNA molecules by thymine DNA glycosylase (TDG) and replaced by cytosine via the process of base excision repair (BER) (Maiti and Drohat 2011, Maiti et al. 2013, Ngo et al. 2016). The knowledge about other suggested mechanisms of demethylation is less comprehensive. They are supposed to include decarboxylation of 5-carboxylcytosine and enzymatic removal of a hydroxymethyl group from 5-hydroxymethylcytosine by the enzymes of the Dnmt family (Shen and Zhang 2013). Two additional pathways initiated by the class of cytidine deaminases - AID (activation-induced cytidine deaminase) and APOBEC (apolipoprotein B mRNA editing enzyme, catalytic polypeptide), can facilitate the deamination of 5-hydroxymethylcytosine. AID enzymes deaminate cytosine bases in DNA to yield uracil. AID and the larger family of APOBEC enzymes have been proposed as factors that affect DNA demethylation by deaminating $5-\mathrm{mC}$ and $5-\mathrm{hmC}$ in DNA to yield thymine and 5-hmU, respectively. As these are present in mismatched $\mathrm{T}: \mathrm{G}$ and $5 \mathrm{hmU}: \mathrm{G}$ base pairs, they are hypothesized to be excised by single-strand-selective monofunctional uracil DNA glycosylase 1, or thymine DNA glycosylase (Pastor et al. 2013).

Active and passive pathways of DNA demethylation may also act synergically in a replicationdependent manner via the formation of 5-mC. A symmetrically-methylated $\mathrm{CpG}$ sequence is converted during DNA replication into two asymmetrically methylated DNA strands. Hemimethylated $\mathrm{CpG}$ sites are recognized by UHRFI, the obligatory partner of the maintenance DNA methyltransferase DNMT1, which restores symmetrical methylation. TET proteins act at methylated $\mathrm{CpG}$ sites to generate symmetrically hydroxymethylated $\mathrm{CpG}$ sequences. 5-hmC and other oxidized methylcytosines may impair maintenance methylation by inhibiting UHRF1 binding, DNMT1 activity, or both. As a result, the $\mathrm{CpG}$ sequence progressively loses DNA methylation through successive DNA replication cycles (Pastor et al. 2013).

\section{Concluding remarks}

The metabolism of 5-mC is considered to be one of the pillars in the process of epigenetic regulation of gene expression shaping the cellular phenotype. The processes leading to aberrant placement of epigenetic marks are important players in the etiology of several severe diseases (Portela and Esteller 2010) such as cancer (Cheray et al. 2013, Pacaud et al. 2014), autoimmune and metabolic diseases including diabetes mellitus (Nilsson et al. 2014, Rönn and Ling 2015). A better understanding of the fundamental biochemical pathways underlying the metabolism of DNA methylation may lead not only to better diagnostic methods (Vasanthakumar and Godley 2015) but also to improved prognosis and therapeutic approaches.

\section{Conflict of Interest}

There is no conflict of interest.

\section{Acknowledgements}

The authors are grateful to Dr. Eva Babušíková (JFM in Martin, CU in Bratislava) for critical reading of the manuscript and her valuable comments. This work was supported by the grants: VEGA 1/0242/13, APVV-022412, APVV-14-0088, and the projects: "CENTER OF TRANSLATIONAL MEDICINE”, ITMS: 26220220021, as well as "Center of excellency for research in personalized therapy", ITMS: 26220120053, co-funded from EU sources and European Regional Development Fund.

\section{References}

AAPOLA U, LIIV I, PETERSON P: Imprinting regulator DNMT3L is a transcriptional repressor associated with histone deacetylase activity. Nucleic Acids Res 30: 3602-3608, 2002.

AHUJA YR, SHARMA S, MOHAN V: Cardiovascular diseases: Interplay of epigenetics. Clin Exp Hypertens 39: 1-7, 2017.

ASLANI S, MAHMOUDI M, KARAMI J, JAMSHIDI AR, MALEKSHAHI Z, NICKNAM MH: Epigenetic alterations underlying autoimmune diseases. Autoimmunity 49: 69-83, 2016.

BÄR C, CHATTERJEE S, THUM T: Long noncoding RNAs in cardiovascular pathology, diagnosis, and therapy. Circulation 134: 1484-1499, 2016. 
BESTOR TH: Activation of mammalian DNA methyltransferase by cleavage of a $\mathrm{Zn}$ binding regulatory domain. EMBO J 11: 2611-2617, 1992.

BRONNER C, KRIFA M, MOUSLI M: Increasing role of UHRF1 in the reading and inheritance of the epigenetic code as well as in tumorogenesis. Biochem Pharmacol 86: 1643-1649, 2013.

CARRICK WT, BURKS B, CAIRNS MJ, KOCERHA J: Noncoding RNA regulation of dopamine signaling in diseases of the central nervous system. Front Mol Biosci 3: 69, 2016.

CHANG H, ZHANG T, ZHANG Z, BAO R, FU C, WANG Z, BAO Y, LI Y, WU L, ZHENG X, WU J: Tissue-specific distribution of aberrant DNA methylation associated with maternal low-folate status in human neural tube defects. J Nutr Biochem 22: 1172-1177, 2011.

CHEN CC, WANG KY, SHEN CK: DNA 5-methylcytosine demethylation activities of the mammalian DNA methyltransferases. J Biol Chem 288: 9084-9091, 2013.

CHEN ZX, RIGGS AD: DNA methylation and demethylation in mammals. J Biol Chem 286: 18347-18353, 2011.

CHERAY M, PACAUD R, NADARADJANE A, VALLETTE FM, CARTRON PF: Specific inhibition of one DNMT1-including complex influences tumor initiation and progression. Clin Epigenetics 5: 9, 2013.

CIECHOMSKA M, O'REILLY S: Epigenetic modulation as a therapeutic prospect for treatment of autoimmune rheumatic diseases. Mediators Inflamm 2016: 9607946, 2016.

D'ALESSIO AC, SZYF M: Epigenetic tête-à-tête: the bilateral relationship between chromatin modifications and DNA methylation. Biochem Cell Biol 84: 463-476, 2006.

DEPLUS R, BRENNER C, BURGERS WA, PUTMANS P, KOUZARIDES T, DE LAUNOIT Y, FUKS F: Dnmt3L is a transcriptional repressor that recruits histone deacetylase. Nucleic Acids Res 30: 3831-3838, 2002.

FEINBERG AP, KOLDOBSKIY MA, GÖNDÖR A: Epigenetic modulators, modifiers and mediators in cancer aetiology and progression. Nat Rev Genet 17: 284-299, 2016.

FERNÀNDEZ-ROIG S, LAI SC, MURPHY MM, FERNANDEZ-BALLART J, QUADROS EV: Vitamin $\mathrm{B}_{12}$ deficiency in the brain leads to DNA hypomethylation in the TCblR/CD320 knockout mouse. Nutr Metab (Lond) 9: 41, 2012.

FRANCHINI DM, SCHMITZ KM, PETERSEN-MAHRT SK: 5-Methylcytosine DNA demethylation: more than losing a methyl group. Annu Rev Genet 46: 419-441, 2012.

GUPTA P, GURUDUTTA GU, SALUJA D, TRIPATHI RP: PU.1 and partners: regulation of haematopoietic stem cell fate in normal and malignant haematopoiesis. J Cell Mol Med 13: 4349-4363, 2009.

GUPTA R, NAGARAJAN A, WAJAPEYEE N: Advances in genome-wide DNA methylation analysis. Biotechniques 49: iii-xi, 2010.

HARIKRISHNAN KN, CHOW MZ, BAKER EK, PAL S, BASSAL S, BRASACCHIO D, WANG L, CRAIG JM, JONES PL, SIF S, EL-OSTA A: Brahma links the SWI/SNF chromatin-remodeling complex with MeCP2-dependent transcriptional silencing. Nat Genet 37: 254-264, 2005.

HO DH, BURGGREN WW: Epigenetics and transgenerational transfer: a physiological perspective. $J$ Exp Biol 213: 3-16, 2010.

HUR SS, CROPLEY JE, SUTER CM: Paternal epigenetic programming: evolving metabolic disease risk. $J$ Mol Endocrinol 58: R159-R168, 2017.

JAMES SJ, MELNYK S, POGRIBNA M, POGRIBNY IP, CAUDILL MA: Elevation in S-adenosylhomocysteine and DNA hypomethylation: potential epigenetic mechanism for homocysteine-related pathology. J Nutr 132: 2361s-2366s, 2003.

KAMAT PK, MALLONEE CJ, GEORGE AK, TYAGI SC, TYAGI N: Homocysteine, alcoholism, and its potential epigenetic mechanism. Alcohol Clin Exp Res 40: 2474-2481, 2016.

KGATLE MM, KALLA AA, ISLAM MM, SATHEKGE M, MOORAD R: Prostate cancer: epigenetic alterations, risk factors, and therapy. Prostate Cancer 2016: 5653862, 2016.

KIM HW, STANSFIELD BK: Genetic and epigenetic regulation of aortic aneurysms. Biomed Res Int 2017: 7268521, 2017.

KLENGEL T, BINDER EB: Epigenetics of stress-related psychiatric disorders and gene $\times$ environment interactions. Neuron 86: 1343-1357, 2015. 
KWAK SH, PARK KS: Recent progress in genetic and epigenetic research on type 2 diabetes. Exp Mol Med 48: e220, 2016.

LIAO HF, TAI KY, CHEN WS, CHENG LC, HO HN, LIN SP: Functions of DNA methyltransferase 3-like in germ cells and beyond. Biol Cell 104: 571-587, 2012.

LIN N, QIN S, LUO S, CUI S, HUANG G, ZHANG X: Homocysteine induces cytotoxicity and proliferation inhibition in neural stem cells via DNA methylation in vitro. FEBS J 281: 2088-2096, 2014.

LISTER R, PELIZZOLA M, DOWEN RH, HAWKINS RD, HON G, TONTI-FILIPPINI J, NERY JR, LEE L, YE Z, NGO QM, EDSALL L, ANTOSIEWICZ-BOURGET J, STEWART R, RUOTTI V, MILLAR AH, THOMSON JA, REN B, ECKER JR: Human DNA methylomes at base resolution show widespread epigenomic differences. Nature 462: 315-322, 2009.

LUDWIG AK, ZHANG P, CARDOSO MC: Modifiers and readers of DNA modifications and their impact on genome structure, expression, and stability in disease. Front Genet 7: 115, 2016.

MAITI A, DROHAT AC: Thymine DNA glycosylase can rapidly excise 5-formylcytosine and 5-carboxylcytosine: potential implications for active demethylation of CpG sites. J Biol Chem 286: 35334-35338, 2011.

MAITI A, MICHELSON AZ, ARMWOOD CJ, LEE JK, DROHAT AC: Divergent mechanisms for enzymatic excision of 5-formylcytosine and 5-carboxylcytosine from DNA. J Am Chem Soc 135: 15813-15822, 2013.

MUND C, LYKO F: Epigenetic cancer therapy: Proof of concept and remaining challenges. Bioessays 32: 949-957, 2010.

NAN X, NG HH, JOHNSON CA, LAHERTY CD, TURNER BM, EISENMAN RN, BIRD A: Transcriptional repression by the methyl-CpG-binding protein MeCP2 involves a histone deacetylase complex. Nature 393: 386-389, 1998.

NGO TT, YOO J, DAI Q, ZHANG Q, HE C, AKSIMENTIEV A, HA T: Effects of cytosine modifications on DNA flexibility and nucleosome mechanical stability. Nat Commun 7: 10813, 2016.

NICULESCU MD, ZEISEL SH: Diet, methyl donors and DNA methylation: interactions between dietary folate, methionine and choline. J Nutr 132 (8 Suppl): 2333S-2335S, 2002.

NILSSON E, JANSSON PA, PERFILYEV A, VOLKOV P, PEDERSEN M, SVENSSON MK, POULSEN P, RIBELMADSEN R, PEDERSEN NL, ALMGREN P, FADISTA J, RÖNN T, KLARLUND PEDERSEN B, SCHEELE C, VAAG A, LING C: Altered DNA methylation and differential expression of genes influencing metabolism and inflammation in adipose tissue from subjects with type 2 diabetes. Diabetes 63: 2962-2976, 2014.

OKANO M, BELL DW, HABER DA, LI E: DNA methyltransferases Dnmt3a and Dnmt3b are essential for de novo methylation and mammalian development. Cell 99: 247-257, 1999.

PACAUD R, BROCARD E, LALIER L, HERVOUET E, VALLETTE FM, CARTRON PF: The DNMT1/PCNA/UHRF1 disruption induces tumorigenesis characterized by similar genetic and epigenetic signatures. Sci Rep 4: 4230, 2014.

PASTOR WA, ARAVIND L, RAO A: TETonic shift: biological roles of TET proteins in DNA demethylation and transcription. Nat Rev Mol Cell Biol 14: 341-356, 2013.

PICCOLO FM, FISHER AG: Getting rid of DNA methylation. Trends Cell Biol 24: 136-143, 2014.

PORTELA A, ESTELLER M: Epigenetic modifications and human disease. Nat Biotechnol 28: 1057-1068, 2010.

PRENDERGAST GC, ZIFF EB: Methylation-sensitive sequence-specific DNA binding by the c-Myc basic region. Science 251: 186-189, 1991.

RASSOULZADEGAN M, GRANDJEAN V, GOUNON P, VINCENT S, GILLOT I, CUZIN F: RNA-mediated non-Mendelian inheritance of an epigenetic change in the mouse. Nature 441: 469-474, 2006.

RAUCH TA, WU X, ZHONG X, RIGGS AD, PFEIFER GP: A human B cell methylome at 100-base pair resolution. Proc Natl Acad Sci U S A 106: 671-678, 2009.

RÖNN T, LING C: DNA methylation as a diagnostic and therapeutic target in the battle against Type 2 diabetes. Epigenomics 7: 451-460, 2015.

SÆTROM P, SNØVE O JR, ROSSI JJ: Epigenetics and microRNAs. Pediatr Res 61: 17R-23R, 2007.

SHEN L, ZHANG Y: 5-Hydroxymethylcytosine: generation, fate, and genomic distribution. Curr Opin Cell Biol 25: 289-296, 2013. 
ŠKOVIEROVÁ H, MAHMOOD S, BLAHOVCOVÁ E, HATOK J, LEHOTSKÝ J, MURÍN R: Effect of homocysteine on survival of human glial cells. Physiol Res 64: 747-754, 2015.

ULREY CL, LIU L, ANDREWS LG, TOLLEFSBOL TO: The impact of metabolism on DNA methylation. Hum Mol Genet 14: R139-R147, 2005.

UPCHURCH GM, HANEY SL, OPAVSKY R: Aberrant promoter hypomethylation in CLL: Does it matter for disease development? Front Oncol 6: 182, 2016.

VASANTHAKUMAR A, GODLEY LA: 5-hydroxymethylcytosine in cancer: significance in diagnosis and therapy. Cancer Genet 208: 167-177, 2015.

WEBER AR, KRAWCZYK C, ROBERTSON AB, KUŚNIERCZYK A, VÅGBØ CB, SCHUERMANN D, KLUNGLAND A, SCHÄR P: Biochemical reconstitution of TET1-TDG-BER-dependent active DNA demethylation reveals a highly coordinated mechanism. Nat Commun 7: 10806, 2016.

WEINBERG MS, MORRIS KV: Transcriptional gene silencing in humans. Nucleic Acids Res 44: 6505-6517, 2016.

WILLIS DE, WANG M, BROWN E, FONES L, CAVE JW: Selective repression of gene expression in neuropathic pain by the neuron-restrictive silencing factor/repressor element-1 silencing transcription (NRSF/REST). Neurosci Lett 625: 20-25, 2016.

WU H, ZHANG Y: Reversing DNA methylation: mechanisms, genomics, and biological functions. Cell 156: 45-68, 2014.

WYSOCKA J, SWIGUT T, XIAO H, MILNE TA, KWON SY, LANDRY J, KAUER M, TACKETT AJ, CHAIT BT, BADENHORST P, WU C, ALLIS CD: A PHD finger of NURF couples histone H3 lysine 4 trimethylation with chromatin remodelling. Nature 442: 86-90, 2006.

YOO CB, JONES PA: Epigenetic therapy of cancer: past, present and future. Nat Rev Drug Discov 5: 37-50, 2006.

ZILBERMAN D, HENIKOFF S: Genome-wide analysis of DNA methylation patterns. Development 134: 3959-3965, 2007. 